\title{
Epidemioclinical Profile of Premature Infants at the Neonatology Unit of the Mali Hospital 2012-2015
}

\author{
Bourama Kané1 ${ }^{*}$, Mamadou Berthé2, Guédiouma Dembélé1, Korotoumou Wélé Diallo1, \\ Diakaridia Koné ${ }^{3}$, Fatou Diawara ${ }^{2}$, Fanta Sidibé2 ${ }^{2}$ Oumou Koné2, Mamadou Coulibaly4, \\ Mariam Maiga $^{5}$, Mariam Sylla ${ }^{6}$
}

${ }^{1}$ Department of Pediatrics, Mali Hospital, Bamako, Mali

${ }^{2}$ National Institute of Public Health, Bamako, Mali

${ }^{3}$ Reference Health Centre of the Commune I, Bamako, Mali

${ }^{4}$ Gynaecological and Obstetric Service, Mali Hospital, Bamako, Mali

${ }^{5}$ Paediatrics Department of the Centre de Santé de Référence de la Commune VI, Bamako, Mali

${ }^{6}$ Gabriel TOURE University Hospital, Bamako, Mali

Email: ^bkanebassidiki.bk@gmail.com

How to cite this paper: Kané, B., Berthé, M., Dembélé, G., Diallo, K.W., Koné, D., Diawara, F., Sidibé, F., Koné, O., Coulibaly, M., Maiga, M. and Sylla, M. (2021) Epidemioclinical Profile of Premature Infants at the Neonatology Unit of the Mali Hospital 2012-2015. Open Journal of Pediatrics, 11, 490-502.

https://doi.org/10.4236/ojped.2021.113046

Received: August 10, 2021

Accepted: September 13, 2021

Published: September 16, 2021

Copyright $\odot 2021$ by author(s) and Scientific Research Publishing Inc. This work is licensed under the Creative Commons Attribution International License (CC BY 4.0).

http://creativecommons.org/licenses/by/4.0/ (c) (i) Open Access

\begin{abstract}
Introduction: A newborn is preterm when it is born before 37 weeks of amenorrhoea. Preterm births account for $11.1 \%$ of live births worldwide, $60 \%$ of which are in South Asia and sub-Saharan Africa. Preterm birth is the leading cause of neonatal mortality and the second leading cause of mortality in children under 5 years of age. The aim of this study was to investigate prematurity in the neonatology unit of the Mali Hospital. Materials and Methods: This was a cross-sectional, descriptive study from January 2012 to December 2015 of premature newborns from 28 to 36 weeks of amenorrhea in the neonatology unit of Mali Hospital. Results: From January 2012 to December 2015, we recorded 1692 inpatient newborns, including 614 preterm newborns, a frequency of $36.29 \%$. The sex ratio was 1.43 in favor of boys. The average age of the mothers was 23.9 years with a minimum of 15 and a maximum of 47 years. The majority were housewives $(92.7 \%)$. The pregnancy was poorly monitored in $51.8 \%$ of the mothers. The average gestational age was 32.9 days with extremes of 25 and 36 days. The most frequent mode of delivery was vaginal delivery (93.2\%), with late prematurity in $51.5 \%$, moderate prematurity (24.4\%), extreme prematurity $(18.7 \%)$ and very premature (5.4\%). The mean birth weight was $1464 \mathrm{~g}$ with a standard deviation of $485 \mathrm{~g}$ and 2751 g. Prematurity was associated with neonatal infection in $49.4 \%$ of newborns, perinatal anoxia (13.9\%) and hypotrophy (2.6\%). The most fre-
\end{abstract}


quent maternal risk factors were fever (83.4\%), twinship (38.9\%) and high blood pressure (8.6\%). The average length of hospitalization was 9.75 days with extremes of 0 and 68 days. We recorded a cure rate of $57.7 \%$, a death rate of $35.7 \%$ and a dropout rate of $6.7 \%$. Conclusion: Prematurity is frequent in the neonatology unit of the Mali Hospital. We observed a high frequency among women of extreme age and low socio-economic and educational level. In our study we also noted a high mortality rate proportional to gestational age.

\section{Keywords}

Epidemioclinical Profile, Prematurity, Mali Hospital

\section{Introduction}

Prematurity is defined by the World Health Organization as the occurrence of birth before 37 completed weeks of amenorrhea (WA) [1]. A distinction is usually made between late prematurity (birth between 34 and $36 \mathrm{WA}$ ), moderate prematurity ( $32-33 \mathrm{WA})$, very premature ( $28-31 \mathrm{WA})$ and very premature (<28 WA) [2].

The incidence of preterm birth varies between countries, regions and socioeconomic conditions, but is still increasing worldwide [3].

An estimated 15 million newborns are born preterm each year, representing one in 10 newborns. Sub-Saharan Africa and South Asia account for nearly 60\% of preterm births worldwide, but it is a global problem. In poor countries, it accounts for $12 \%$ of live births compared to $9 \%$ in high-income countries [4].

Among the ten countries with the highest prematurity rates are eight African countries: Malawi (18.1\%), Comoros (16.7\%), Congo (16.7\%), Zimbabwe (16.6\%), Equatorial Guinea (16.5\%), Mozambique (16.4\%), Gabon (16.3\%) and Mauritania (15.4\%) [4].

Prematurity is the leading cause of death among newborns, accounting for $75 \%$ of neonatal mortality and the second leading cause of death among children under 5 years of age [4] [5] [6]. Of the 15 million premature babies born each year, more than 1 million die from complications. Many survivors suffer lifelong sequelae, including learning disabilities, visual and hearing impairments [4].

Survival rate for prematurity shows striking inequalities across countries. In low-income countries, half of all newborns at 32 weeks of amenorrhea die because of lack of feasible and affordable care such as warmth, breastfeeding and basic care for infections and respiratory distress. In high-income countries almost all of these premature babies survive [4].

In Mali, 88,000 newborns are born prematurely and 9170 children under five years of age die from complications directly related to preterm birth [7].

The main risk factors associated with preterm birth are: 
- Sociodemographic risk factors: maternal age, socio-educational and economic level, hard work, stress and addictions.

- Medical and obstetrical complications: multiple pregnancies, urogenital infections, chronic diseases (diabetes, hypertension), uterine malformations [4] [8].

Frequently, however, the cause is not identified. The mechanisms by which these different factors are linked to prematurity are not clearly elucidated [4] [8].

In Mali, the main maternal risk factors for prematurity are: solid fuel for indoor cooking (99\%), anemia (51\%) and high blood pressure (34\%) [7].

This work was initiated to study the epidemiological and clinical aspects of premature newborns from 25 to 35 weeks of amenorrhea in the neonatology unit of the Mali Hospital.

\section{Objectives}

\section{1) Overall objective:}

To study the epidemiological and clinical characteristics of preterm newborns from 25 to 36 weeks of amenorrhea in the neonatology unit of the Mali Hospital.

2) Specific objectives:

- To determine the frequency of premature newborns between 25 and 36 weeks of amenorrhea in the neonatology unit of the Mali Hospital;

- To describe the socio-demographic characteristics of premature newborns from 25 to 36 weeks of amenorrhea in the neonatology unit of the Mali Hospital;

- Describe the clinical aspects;

- To determine the clinical evolution of premature infants within the hospital.

\section{Materials and Methods}

\subsection{Study Setting}

The pediatric service of the Mali Hospital was our study setting. It was composed of a general pediatrics unit and a neonatology unit. The neonatology unit was equipped with 4 incubators, 4 heating lamps, 2 phototherapy devices, 4 wall vacuum cleaners, 1 bilirubinometer, 1 glucometer, 12 oxygen intakes, and 10 cribs. The neonatology staff consisted of 10 agents including a neonatologist pediatrician, a general pediatrician, a medical assistant head of unit and 8 obstetric nurses. It received newborns on a permanent basis with a day and night team.

\subsection{Type and Period of Study}

We conducted a retrospective, descriptive cross-sectional study from January 2012 to December 2015.

\subsection{Study Population}

\subsubsection{Target Population}

All premature newborns between 25 and 36 weeks of amenorrhea hospitalized 
during the period in the neonatology unit of the hospital in Mali.

\subsubsection{Inclusion Criteria}

Included were records of preterm neonates 25 to 36 weeks of amenorrhea hospitalized in the neonatal unit from January 2012 to December 2015.

\subsubsection{Criteria for Non-Inclusion}

Not included in our study were:

- Preterm newborns less than 25 weeks of amenorrhea;

- Full-term newborns;

- Newborns with incomplete, poorly archived or unusable records.

\subsection{Variables}

The following variables were studied:

- Socio-demographic variables such as mothers' age, parents' occupation and education level, newborn's age, sex, origin.

- Clinical and evolutionary variables.

$\checkmark$ Of the mother, such as: maternal medical and surgical history (notion of diabetes, arterial hypertension, asthma, hernia), gyneco-obstetrical history (parity, mode of delivery, notion of rupture of the water bags, appearance of the amniotic fluid, abnormalities of the heart sounds).

$\checkmark$ Of the newborn, such as the notion of resuscitation at birth, weight, height, trophicity, body temperature, time to consultation, clinical signs, duration of hospitalization and the patient's outcome.

- Biological variables.

$\checkmark$ Of the mother, such as toxoplasmosis, rubella, syphilis and Hbs antigen serology.

$\checkmark$ Of the newborn, such as blood count, C-reactive protein.

\subsection{Data Collection Tools}

The study consisted of examining the medical records of preterm newborns between 25 and 36 weeks of amenorrhea in order to include those that were usable in our study. The data were collected using a survey form developed for this purpose. The questionnaire included the socio-demographic data of the parents and the newborn, the mother's medical and surgical and gyneco-obstetrical history, the newborn's clinical data, the mother's and the newborn's biological data, and the newborn's outcome.

\subsection{Data Collection Technique}

The data were collected through the patients' hospitalization records, completed if necessary by the hospitalization and discharge registers.

\subsection{Data Processing}

The data will be entered using Excel 216 and analyzed by SPSS 21.0. The report 
was written using Word.

\subsection{Ethical Aspects}

For the use of the data, the authorization of the hospital management was requested because the sole purpose of this research is to improve the care of premature newborns. As the study was done on the files, there was no disadvantage for the patients or their parents, therefore no financial compensation was paid. The anonymity and confidentiality of the patients were respected in accordance with the rules of medical ethics and the legislation on biomedical and scientific research. No names were included in the database except for the file numbers.

The data were kept on the computers of the principal investigator and the co-investigator. Only they had access to the database entry code.

\section{Results}

During the period we recorded 1692 hospitalized newborns including 614 premature newborns, i.e. a prevalence of $36.29 \%$. Of all hospitalizations of all ages in the pediatric department, this frequency was $12.95 \%$.

The majority of the mothers, 63\%, were in the age group [15 - 25 years]. Three hundred and fifty of the 614 mothers (57\%) were uneducated and the vast majority were housewives (Table 1).

Table 1. Distribution of preterm infants by sociodemographic characteristics of mothers at Mali Hospital from January 2012 to December 2015.

\begin{tabular}{|c|c|c|}
\hline Age range of mothers & $\mathrm{N}=614$ & $\%$ \\
\hline [15 - 25 years old] & 387 & 63.0 \\
\hline [26 - 35 years old] & 178 & 29.0 \\
\hline [36 - 45 years old] & 48 & 7.8 \\
\hline$>45$ years old & 1 & 0.2 \\
\hline Total & 614 & 100.0 \\
\hline Education level of mothers & $\mathrm{N}=614$ & $\%$ \\
\hline Not educated & 350 & 57.0 \\
\hline Primary level & 163 & 26.5 \\
\hline Secondary level & 55 & 9.0 \\
\hline Upper level & 46 & 7.5 \\
\hline Total & 614 & 100.0 \\
\hline Mother occupation & $\mathrm{N}=614$ & $\%$ \\
\hline Housekeeper & 569 & 92.7 \\
\hline Unemployed & 20 & 3.3 \\
\hline Employee & 17 & 2.8 \\
\hline Shopkeeper & 8 & 1.3 \\
\hline Total & 614 & 100.0 \\
\hline
\end{tabular}


Arterial hypertension was the most frequent medical history among the mothers ( 9 mothers out of 614 , i.e., $1.5 \%$ ), $41.2 \%$ of the mothers were pauciparous, $51.8 \%$ of the pregnancies were not well monitored, and $93.2 \%$ of the deliveries were made naturally (Table 2).

More than half of our premature infants (51.2\%) were male, $51.5 \%$ had a gestational age between [ $34-36 \mathrm{WA}$ ], $50.2 \%$ were born in a reference health center (2nd level health center) (Table 3).

The birth weight was $<1500 \mathrm{~g}$ in $55.4 \%$ of our premature infants, $51.5 \%$ of them had late prematurity, the recovery rate was $57.7 \%$, the death rate was $35.7 \%$ and the dropout rate was $6.7 \%$ (Table 4 ).

\section{Comments and Discussion}

Despite the limitations of this study related to its retrospective nature, poor record keeping, the non-availability of certain complementary examinations in our hospital, and the fact that it was carried out only in the neonatology unit of the Hôpital du Mali, the results obtained made it possible to highlight the problems of premature newborns in our department.

Table 2. Distribution of preterm infants by maternal medical-surgical and gyneco-obstetrical history at Mali Hospital from January 2012 to December 2015.

\begin{tabular}{|c|c|c|}
\hline Medical and surgical history & $\mathrm{N}=614$ & $\%$ \\
\hline Asthma & 1 & 0.2 \\
\hline Cesarean section & 3 & 0.5 \\
\hline Diabetes & 1 & 0.2 \\
\hline Umbilical hernia & 1 & 0.2 \\
\hline High blood pressure & 9 & 1.5 \\
\hline No history & 599 & 97.6 \\
\hline Total & 614 & 100.0 \\
\hline Parity & $\mathrm{N}=614$ & $\%$ \\
\hline Primiparous $(0-1)$ & 248 & 40.4 \\
\hline Paucipare $(2-4)$ & 253 & 41.2 \\
\hline Multipare (5 - 6) & 72 & 11.7 \\
\hline Large multiparous (7 - 13) & 41 & 6.7 \\
\hline Total & 614 & 100.0 \\
\hline Pregnancy follow-up & $\mathrm{N}=614$ & $\%$ \\
\hline Well followed (Prenatal consultation $>3$ ) & 154 & 25.1 \\
\hline Mal suivie (Prenatal consultation $=1-3$ ) & 318 & 51.8 \\
\hline Non suivie (Prenatal consultation $=0$ ) & 142 & 23.1 \\
\hline Total & 614 & 100.0 \\
\hline Mode of delivery & $\mathrm{N}=614$ & $\%$ \\
\hline Lower track & 572 & 93.2 \\
\hline Cesarean section & 42 & 6.8 \\
\hline Total & 614 & 100.0 \\
\hline
\end{tabular}


Table 3. Distribution of premature infants by sociodemographic characteristics at Mali Hospital from January 2012 to December 2015.

\begin{tabular}{ccc}
\hline Gender & $\mathbf{N}=\mathbf{6 1 4}$ & $\%$ \\
\hline Male & 317 & 51.6 \\
Female & 297 & 48.4 \\
Total & 614 & 100.0 \\
\hline Gestational age class & $\mathbf{N}=614$ & $\%$ \\
\hline$[<28$ WA $]$ & 33 & 5.4 \\
{$[28-31$ WA $]$} & 115 & 18.7 \\
{$[32$ - 33 WA $]$} & 150 & 24.4 \\
{$[34-36$ WA $]$} & 316 & 51.5 \\
Total & 614 & 100.0 \\
\hline Place of birth & $\mathbf{N}=614$ & $\%$ \\
\hline Community health center & 233 & 37.9 \\
Reference health center & 308 & 50.2 \\
Hospital & 22 & 3.6 \\
Private structures & 41 & 6.7 \\
Home & 10 & 1.6 \\
Total & 614 & 100.0 \\
\hline
\end{tabular}

Table 4. Distribution of newborns according to their clinical and evolutionary characteristics at the Mali Hospital from January 2012 to December 2015.

\begin{tabular}{ccc}
\hline Weight class & $\mathbf{N}=614$ & $\%$ \\
\hline$[<1500 \mathrm{~g}]$ & 340 & 55.4 \\
{$[1500-1999 \mathrm{~g}]$} & 224 & 36.5 \\
{$[2000-2499 \mathrm{~g}]$} & 49 & 8.0 \\
{$[2500-2999 \mathrm{~g}]$} & 1 & 0.2 \\
Total & 614 & 100.0 \\
\hline Diagnosis & $\mathbf{N}=614$ & $\%$ \\
\hline Very premature & 33 & 5.4 \\
Extreme prematurity & 115 & 18.7 \\
Moderate prematurity & 150 & 24.4 \\
Late prematurity & 316 & 51.5 \\
Total & 614 & 100.0 \\
\hline Evolution & $\mathbf{N}=614$ & $\%$ \\
\hline Healing & 354 & 57.7 \\
Deaths & 219 & 35.7 \\
Abandonments & 41 & 6.7 \\
\hline Total & 614 & 100.0 \\
\hline
\end{tabular}




\section{Frequency}

During our study which covered the period from January 2012 to December 2015 i.e. a period of 47 months, we recorded 1692 newborns including 614 premature newborns i.e. a prevalence of $36.29 \%$. Our frequency is largely higher than the WHO estimates which was $11.1 \%$ of all live births in 2011 reported by TORCHIN H. (2015) [9]. It is also higher than those found by most authors including DICKO F. T. et al. [10]. in 2014 in Bamako, KOUAKOU C et al. [11] in 2016 in Abidjan and SOW et al. [12] in Dakar in 2018 who respectively reported frequencies of $30.2 \%, 27.6 \%$ and $28.1 \%$. Our high frequency can be explained by the geographical location of our service. It is located in a peri-urban area on the right bank of Bamako and is the only structure capable of receiving premature newborns in this area.

\section{Characteristics of the Mothers}

\subsection{Socio-Demographic Characteristics of the Mothers}

- According to age

The majority of the women in our sample were between 15 and 25 years of age ( $63 \%$ or $387 / 614$ ), followed by those between 26 and 35 years of age ( $29 \%$ or 178 out of 614). A minority of $8 \%$ were 36 years and older ( 49 out of 614 ). Our data are close to those of the literature LACROZE V. [8] and TORCHIN H. [2] who reported that the overall risk of prematurity is higher in young women $(<18$ years) and in older women ( $>35$ years). This risk is explained by social and medical factors. Our results are slightly different from those of ZINI et al. [13] in 2019 who found in Ghana a high frequency only in the age category [30 - 34 years] (36.8\%).

- By occupation

Housewives were in the majority in our sample $(92.7 \%$ or $569 / 614)$, followed by the unemployed $(3.3 \%$ or $20 / 614)$, salaried employees $(2.8 \%$ or $17 / 614)$ and shopkeepers $(1.3 \%$ or $8 / 614)$. Our results are superior to those of other authors. DIOUF F.N. et al. [14] in Senegal in 2011 found that $72.2 \%$ of the mothers in their study were not professionally active. FISTON M. et al. [15] in 2018 in the Democratic Republic of Congo found a frequency of $45.8 \%$ of housewives in their series. Our high frequency of housewives can be explained by the predominance of housewives in the general population.

- According to the level of education

More than half of the mothers (57\%) were not educated. The primary level represented $26.5 \%$, secondary (9\%) and higher (7.5\%). Our results are consistent with the data in the literature (LACROZ V [8], LEJEUNE [16], and those reported by other authors). DIOUF F. N. et al. [14] in Senegal in 2011 showed that $48.1 \%$ of mothers in their series were not educated. BELINGA E. et al. [17] in 2015 showed that parturients referred to the maternity ward of the Yaoundé Gyneco-Obstetrics and Pediatrics Hospital had a majority of primary education (OR = 2.13 (IC 95\%: 1.19 - 3.81); $\mathrm{p}=0.007$ ) and were more likely to have a premature 
newborn than non-referred parturients $(\mathrm{RR}=1.80(\mathrm{IC}: 1.40-2.32) ; \mathrm{p}=0.001)$.

\subsection{Clinical Characteristics of the Mothers}

- In our study, maternal pathologies associated with prematurity were dominated by maternal fever (83.4\%), gemellity (38.9\%) and arterial hypertension (8.6\%). Our results are superimposed on the data in the literature LACROZE $\mathrm{V}$ [8] and those reported by some authors including SOW et al. [12] in Senegal in 2018 found that genitourinary infection was predominantly frequent (27.7\%) followed by arterial hypertension (23.4\%) and preeclampsia (8.5\%). FISTON M et al. [15] in 2018 in the Democratic Republic of Congo observed that urinary tract infection was associated with prematurity in $75 \%$ of women followed by malaria (25\%) and hypertension ( $8 \%)$.

- According to parity

The majority of our mothers were pauciparous (41.2\%) and primiparous (40.4\%) followed by multiparous (11.7\%) and grand multiparous (6.7\%). Our results are different from those reported by some authors. FISTON M et al. [15] in 2018 in the Democratic Republic of Congo found a preterm delivery frequency of $41.7 \%$ in large multiparous women, $33.3 \%$ in multiparous women, $16.7 \%$ in primiparous women and $8.3 \%$ in pauciparous women. TORCHIN H [2] who, after a meta-analysis published in 2010 regrouping data from developed countries did not find an association between parity and the overall risk of prematurity for multiparous women (OR $=1.1, \mathrm{CI} 95 \%$ [1.0 - 1.3], 6 studies) or large multiparous women (parity 5 to 9: $\mathrm{OR}=1.0, \mathrm{CI} 95 \%$ [0.8 - 0.2], 12 studies).

- According to pregnancy follow-up

More than half of our mothers (74.9\%) had less than 4 prenatal visits. This result is higher than those reported by authors such as MASMAOUI El et al. [18] in 2009 in Morocco and SOW A et al. [12] in 2018 in Senegal who respectively found a rate of $31 \%$ and $25.5 \%$.

- Depending on the route of delivery

Of the 614 premature babies, 572 were born by the vaginal route, i.e. a proportion of $93.2 \%$. This frequency is much higher than those reported by DIOUF [14], AMRI [19] and MASMAOUI [18] who found frequencies of $81.7 \%, 74.4 \%$ and $72.5 \%$ respectively.

\section{Characteristics of Premature Babies}

\subsection{Socio-Demographic Characteristics of Premature Babies}

\section{- According to gestational age}

The majority of the subjects in the study had a gestational age between 34 and 36 WA (51.5\%), followed by premature babies of [32 - $33 \mathrm{WA}$ ] (24.4\%), [28 - 31 $\mathrm{WA}$ ] (18.7\%) and the GA class of [<28 WA] [5.4\%]. KOUAKOU C et al. [11] in 2016 found the same results with a predominance in the gestational age range [34 - $36 \mathrm{WA}$ ] (51.6\%) [11]. They are superposable to those found by SOW et al. [12] in Dakar in 2018 observed a high frequency in the GA bracket [33 - 36 WA] 
(83\%) [20].

- According to gender:

In our series we found a male predominance (51.6\%) with a sex ratio of 1.4 in favor of boys. Our result is different from the results reported by other authors, notably those of DIOUF F.N. et al. [14] in Senegal in 2011 and DAINGUY M.E. et al. [21] in 2015 in Ivory Coast. They found respectively sex ratios of 0.77 and 0.90 in favor of girls. SOW et al. [12] in Dakar in 2018 and KOUAKOU C et al. [11] in 2016 did not observe a difference between the 2 sexes in their series with sex ratios of 1.07 and 1.01 respectively.

- According to the place of birth:

More than half of our premature infants came from a referral health center (50.2\%), (37.9\%) from a community health center, (6.7\%) came from a private facility, (3.6\%) from the hospital, and (1.6\%) came from home. This result is different from that of KOUAKOU C et al. [11] in 2016 in which $70.4 \%$ of births took place at the university hospital center and $29.6 \%$ outside the university hospital center. They are also different from the results of the study of AMRI et al. [19] in 2008 in Tunisia who found that $85 \%$ of premature babies were transferred from the central maternity of the Regional Hospital of Kairouan to the neonatology unit of the hospital of Kairouan, 9\% came from a peripheral maternity, $3 \%$ at home and $0.8 \%$ from private structures. This difference in origin can be explained by the organization of the health system in Mali.

\subsection{Clinical Characteristics of Premature Infants}

- According to the time of admission

A large proportion of our premature babies $(94,6 \%)$ were admitted before 24 hours of life, $(2.4 \%)$ between 24 and 72 hours of life and $2.9 \%$ beyond 72 hours of life. This figure is similar to that of KOUAKOU C. et al. [11] in 2016 who showed that $79.8 \%$ of premature babies in their study were admitted before the first 6 hours of life. It is higher than that of DIOUF F. N. et al. [14] in Senegal in 2011 who revealed that $58.6 \%$ are admitted before the first 24 of life.

- According to the type of prematurity

In our study, late prematurity was in the majority (51.5\%), followed by moderate prematurity $(24.4 \%)$, extreme prematurity $(18.7 \%)$ and very extreme prematurity (5.4\%). This result is close to that of TORCHIN H. et al. [9] in 2015, in France found $85 \%$ of moderate prematurity ( 32 - 33 WA) or late prematurity (34 - $36 \mathrm{WA}), 10 \%$ of great prematurity ( $28-31 \mathrm{WA})$ and $5 \%$ of very great prematurity $(<28 \mathrm{WA})$.

- According to the birth weight

In our series, those under $1500 \mathrm{~g}$ were the most represented $(55.4 \%, 340 / 614)$ followed by the weight ranges [1500 - $1999 \mathrm{~g}$ ] (36.4\%, 224/614), [2000 - $2499 \mathrm{~g}$ ] $(8 \%, 49 / 614)$ and $[2500-2999 \mathrm{~g}](0.2 \%, 1 / 614)$. These data are different from those of KOUAKOU C. et al. [11] 2016 in Abidjan who observed in their study that $72.3 \%$ of premature infants weighed more than $1500 \mathrm{~g}$. It is also different 
from those of BUTALI A. et al. [22] in 2015 who found a frequency peak $(41.8 \%)$ in the weight range [1500 - $2499 \mathrm{~g}]$.

- According to the associated pathologies

Prematurity was associated with neonatal infection in $49.4 \%$ of our newborns, with perinatal anoxia (13.9\%) and with hypotrophy (2.6\%). Our data are superimposed on the data in the literature and those reported by other authors with varying proportions. CASTAIGNE [23] reported that infections, respiratory distress and cerebral distress are associated with prematurity in $75 \%$ of cases. DIOUF et al. [14] found in their study that neonatal infection was associated with prematurity in $41.6 \%$ of newborns followed by jaundice $(29.7 \%)$ and hypoglycemia (13.1\%). Our results are slightly different from those reported by KOUAKOU C et al. [11] who observed in their series an association with metabolic disorders in $60.8 \%$ of newborns, neonatal infection $(45.1 \%)$ and anemia (17.8\%).

- According to the average length of hospitalization

The average length of hospitalization of our premature babies is 9.75 days with extremes of 0 and 68 days. Our figures are lower than those of MAMAOUI et al. [18] and DIOUF et al. [14] who respectively reported an average length of hospitalization of 19.36 and 24 days. This can be explained by the predominance of late (51.5\%) and moderate (24.4\%) prematurity in our study.

- According to the evolution

We recorded $57.5 \%$ recovery, $35.7 \%$ death and $6.7 \%$ dropout. Our mortality rate is lower than that of MASMAOUI et al. [18] in Morocco in 2009 and DIOUF et al. [14] in Senegal in 2011 who respectively recorded mortality rates of $40.5 \%$ and $50.5 \%$. It is higher than those of KOUAKOU C et al. [11] and SOW et al. [12] who respectively recorded death rates of $18.3 \%$ and $9.2 \%$. This high mortality rate is consistent with the overall mortality rate of premature infants in developing countries due to the existence of several maternal risk factors, but also to the lack of hygiene and the inadequacy of technical facilities.

\section{Conclusion}

Prematurity is frequent in the neonatology unit of the Mali Hospital. We observed a high frequency in women of extreme age and low socioeconomic and educational level. Late prematurity was the predominant clinical form in our sample. In our study we also found a high mortality rate proportional to gestational age.

\section{Conflicts of Interest}

The authors declare no conflicts of interest regarding the publication of this paper.

\section{References}

[1] OMS. Incidence mondiale de la naissance avant terme: Revue systématique de la mortalité et de la morbidité maternelle. 
[2] Torchin, H. and Ancel, P.-Y. (2016) Épidémiologie et facteurs de risque de la prématurité. Journal de Gynécologie Obstétrique et Biologie de la Reproduction, 45, 1213-1230. https://doi.org/10.1016/j.jgyn.2016.09.013

[3] Cohen-Solal, E. and Cravello, L. (2010) Évolution de la prématurité-Evolution of preterm birth. 4 .

[4] Naissances prématurées. https://www.who.int/fr/news-room/fact-sheets/detail/preterm-birth

[5] Houssoune, S., Tsoumbou, B. and Boussouf, N. (2018) Ampleur de la prématurité dans les pays du grand magreb. Artcle tinusien médical.com.

[6] lancet_neonatal_survival_series_fr.pdf. https://www.who.int/maternal child adolescent/documents/pdfs/lancet neonatal s urvival series fr.pdf?ua $=1$

[7] Mali2017_french1.pdf. https://www.healthynewbornnetwork.org/hnn-content/uploads/Mali2017 french1. pdf

[8] Prématurité, L.V. (2011) Définitions, épidémiologie, étiopathogénie, organisation des soins. In: EMC pédiatrie, Masson-Elsevier, Paris, 1-7. https://doi.org/10.1016/S1637-5017(11)72497-8

[9] Torchin, H., Ancel, P.-Y., Jarreau, P.-H. and Goffinet, F. (2015) Épidémiologie de la prématurité: Prévalence, évolution, devenir des enfants. Journal de Gynécologie Obstétrique et Biologie de la Reproduction, 44, 723-731.

https://doi.org/10.1016/j.jgyn.2015.06.010

[10] Dicko-Traoré, F., Sylla, M., Traoré, Y., Traoré, A., Diall, H., Diakité, A.A., et al. (2014) Unité de néonatologie de référence nationale du Mali: État des lieux. Sante Publique (Bucur), 26, 115-121. https://doi.org/10.3917/spub.137.0115

[11] Kouakou, C., Dainguy, M. and Kouadio, E. (2016) Facteurs de risque de deces du premature dans un service de reference a abidjan. Revue Internationale des Sciences Médicales, 18, 35-41.

[12] Sow, A., Gueye, M., Boiro, D., Ndongo, A.A., Coundoul, A.M., Diouf, S., et al. (2018) Prématurité: Épidémiologie et facteurs étiologiques dans une maternité de Dakar (Sénégal). Journal de Pédiatrie et de Puériculture, 31, 91-95. https://doi.org/10.1016/j.jpp.2018.02.001

[13] Zini, M.E. and Omo-Aghoja, L.O. (2019) Clinical and Sociodemographic Correlates of Preterm Deliveries in Two Tertiary Hospitals in Southern Nigeria. Ghana Medical Journal, 53, 20-28. https://doi.org/10.4314/gmj.v53i1.4

[14] Diouf, F.N. (2017) Aspects socio-démographiques, épidémiologiques, cliniques et pronostiques de la prématurité dans l'unité de néonatologie de l'hôpital d'enfant Albert Royer de Dakar/Sénégal. Rev Afr Malgache Rech Sci Santé, 4, 19-23.

[15] Mbayo, F.I., Nsenga, Y.B., Lupitshi, G.K., Nyemba, K.T., Mpingisha, C.M., Kambala, J.B., et al. (2020) The Determinants of Premature Birth during the Year 2018 at the General Reference Hospital of Malemba in the Democratic Republic of Congo. The Pan African Medical Journal, 37, 30. https://doi.org/10.11604/pamj.2020.37.30.25205

[16] Lejeune, C. (2008) Précarité et prématurité. Journal de Pédiatrie et de Puériculture, 21, 344-348. https://doi.org/10.1016/j.jpp.2008.09.008

[17] Belinga, E., Foumane, P., Dohbit, S.J., Ngo Um, E.M., Kiyeck, D.K. and Mboudou, E.T. (2017) Pronostic des références obstétricales à l'Hôpital Gynéco-Obstétrique et Pédiatrique de Yaoundé (HGOPY). The Pan African Medical Journal, 28, 301. 
https://doi.org/10.11604/pamj.2017.28.301.10773

[18] El Masnaoui, N., Barkat, A., Hatou, F., Kabiri, M. and Lamdouar Bouazzaoui, N. (2009) Facteurs impliqués dans la mortalité périnatale des nouveau-nés issus de grossesses multiples de haut rang. Journal de Pédiatrie et de Puériculture, 22, 193-196. https://doi.org/10.1016/j.jpp.2009.05.005

[19] Amri, F., Fatnassi, R., Negra, S. and Khammari, S. (2008) Prise en charge du nouveau-né prématuré. Journal de Pédiatrie et de Puériculture, 21, 227-231. https://doi.org/10.1016/j.jpp.2008.04.019

[20] Sow, A., Gueye, M., Boiro, D., Ndongo, A.A., Coundoul, A.M., Diouf, S., et al. (2018) Prématurité: Épidémiologie et facteurs étiologiques dans une maternité de Dakar (Sénégal). Journal de Pédiatrie et de Puériculture, 31, 91-95.

[21] Dainguy, M., Folquet, A. and Akaffou, M. (2011) Suivi ambulatoire du premature la premiere annee de vie au service de pediatrie du chu de cocody. Le Mali médical, 26, 25-29.

[22] Butali, A., Ezeaka, C., Ekhaguere, O., Weathers, N., Ladd, J., Fajolu, I., et al. (2016) Characteristics and Risk Factors of Preterm Births in a Tertiary Center in Lagos, Nigeria. The Pan African Medical Journal, 24, Article No. 1.

https://doi.org/10.11604/pamj.2016.24.1.8382

[23] Castaigne, V., Picone, O. and Frydman, R. (2005) Accouchement du prématuré. EMC-Gynécologie-Obstétrique, 2, 354-363.

https://doi.org/10.1016/j.emcgo.2005.09.001 